Published in final edited form as:

Semin Diagn Pathol. 2011 May ; 28(2): 167-177.

\title{
Molecular Pathogenesis of Diffuse Large B-cell Lymphoma
}

\author{
Christof Schneider, M.D. ${ }^{1}$ [Postdoctoral Researcher], Laura Pasqualucci, M.D. ${ }^{1,2}$ \\ [Associate Professor], and Riccardo Dalla-Favera, M.D. ${ }^{1,2,3,{ }^{*}}$ [Uris Professor] \\ ${ }^{1}$ Institute for Cancer Genetics, Columbia University, New York, NY 10032 \\ 2Department of Pathology and Cell Biology, Columbia University, New York, NY 10032 \\ ${ }^{3}$ Department of Genetics and Development, Columbia University, New York, NY 10032
}

\begin{abstract}
Over the past years, substantial insight regarding the pathogenesis of diffuse large B-cell lymphoma has been obtained. Particularly, based on gene expression profile analysis this disease can be classified in distinct phenotypic subgroups and specific transcriptional programs have been identified. New technologies like next-generation whole genome/exome sequencing and genome wide SNP array analysis revealed novel lesions involved in the pathogenesis of this disease. This Review focuses on the diversity of genetic lesions found in the different subtypes of diffuse large B-cell lymphoma.
\end{abstract}

\section{Introduction}

Diffuse Large B-Cell Lymphoma (DLBCL) is the most common type of Non-HodgkinLymphoma (NHL), accounting for about $40 \%$ of NHL cases ${ }^{1}$. DLBCL is a heterogeneous disease with a highly variable clinical course, currently treated with combinations of immuno- and chemotherapy. Based on gene expression profile analysis, this single diagnostic category can be classified into distinct phenotypic subtypes, differing in molecular and clinical features and reflecting the origin from specific stages of B cell differentiation during the germinal center reaction ${ }^{2}$. During the past decade, multiple recurrent genetic alterations associated with DLBCL have been identified. This review will provide a brief summary of the germinal center reaction as a basis to understand the biological heterogeneity of DLBCL, and then focus on individual genetic lesions contributing to the pathogenesis of this disease.

\section{Most DLBCLs derive from Germinal Center B-cells}

The germinal center (GC) is the site where B-cells undergo distinct genetic processes to generate high-affinity antibodies (Fig 1). GCs are formed by proliferating B-cells in secondary lymphoid tissues upon T-cell dependent antigen stimulation. Within the dark zone

\footnotetext{
(C) 2011 Elsevier Inc. All rights reserved.

*(Corresponding author): Uris Professor of Pathology and Genetics, Director, Institute for Cancer Genetics, Columbia University, 1130 St. Nicholas Avenue, New York, NY 10032, Tel (212) 851-5273, Fax (212) 851-5256, rd10@ columbia.edu.

Christof Schneider, M.D., Postdoctoral Researcher, Institute for Cancer Genetics, Columbia University, 1130 St. Nicholas Avenue, New York, NY 10032; Laura Pasqualucci, M.D., Associate Professor of Clinical Pathology and Cell Biology, Institute for Cancer Genetics, Columbia University, 1130 St. Nicholas Avenue, New York, NY 10032, Tel (212) 851-5248, Fax (212) 851-5256, 1p171@columbia.edu

Publisher's Disclaimer: This is a PDF file of an unedited manuscript that has been accepted for publication. As a service to our customers we are providing this early version of the manuscript. The manuscript will undergo copyediting, typesetting, and review of the resulting proof before it is published in its final citable form. Please note that during the production process errors may be discovered which could affect the content, and all legal disclaimers that apply to the journal pertain.
} 
of the GC, which consists of highly proliferating centroblasts (CBs), the cells undergo somatic hypermutation (SHM) of the variable region of the immunoglobulin gene $(\operatorname{IgV})^{3-4}$. SHM produces primarily single nucleotide substitutions, but also deletions and duplications in the IgV heavy and light chain genes, resulting in the production of antibodies with high affinity for the antigen ${ }^{3-5}$. SHM can also target a number of non-immunoglobulin genes in normal B-cells, for example the $5^{\prime}$ untranslated region of B-cell lymphoma 6 (BCL-6) ${ }^{6-8}$. SHM occurs via DNA strand breaks and requires activation-induced cytidine deaminase (AID), which initiates the process by converting deoxycytidines to uracils, which are then further processed by DNA repair enzymes, leading to the creation of abasic sites and errorprone repair ${ }^{9-11}$.

The initiation and maintenance of the GC is dependant on BCL-6, a transcriptional repressor belonging to the BTB/POZ/ZincFinger family of transcription factors. BCL-6 is essential in the GC reaction, as evidenced by the observation that mice lacking BCL- 6 cannot form GCs nor can produce high affinity antibodies ${ }^{12-13}$. BCL-6 is highly expressed in CBs, where it directly binds to and represses more than 1200 genes, as recently identified through integrated biochemical, functional and bioinformatics approach ${ }^{14}$. BCL-6 target genes are involved in a variety of signaling pathways that are important for the GC reaction, including: i) DNA damage response, ii) apoptosis iii) plasma cell differentiation, iv) B-cell receptor (BCR) signaling, v) CD40 signaling, vi) TNF $\beta$ signaling, vii) Interferon (INF) signaling, viii) Toll-like receptor (TLR) signaling and ix) WNT signaling as well as $\mathrm{x}$ ) T-cell mediated activation ${ }^{14-22}$. Taken together, these data indicate that BCL-6 is essential for the rapid proliferation of $\mathrm{CBs}$, while allowing GC B-cells to undergo DNA modifications without inducing an unwanted DNA-damage response. Furthermore, BCL-6 inhibits the expression of several transcription factors that are essential for plasma cell differentiation 14,17-18,23-24.

In the light zone of the germinal center, $\mathrm{CBs}$ differentiate into centrocytes $(\mathrm{CCs})$, which are re-challenged by the antigen in order to allow the selection for B-cells that produce highaffinity antibodies, while cells with a low-affinity Ig-receptor are eliminated by apoptosis 25 . Furthermore, CCs undergo class-switch recombination (CSR), an intrachromosomal DNA recombination event that confers distinct effector functions to the antibodies by changing their immunoglobulin class from IgD and IgM to IgG, IgA or IgE ${ }^{26}$. CSR occurs via nonhomologous end-joining and requires AID ${ }^{27-28}$. Another critical process that is initiated in the light zone of the GCs is the differentiation of B-cells with high-affinity Ig-receptor into effector plasma cells or memory B-cells. The down-regulation of BCL-6 is essential to allow terminal B-cell differentiation, and is accomplished in these cells through at least two distinct mechanisms, i.e. activation of CD40 and stimulation of the BCR. CD40 activation via CD40 ligand, expressed on CD4+ T cells, leads to NF- $\mathrm{kB}$-mediated activation of interferon regulatory factor 4 (IRF4) and subsequent transcriptional silencing of BCL- $6{ }^{29-30}$. The stimulation of the BCR promotes mitogen-activated protein kinases (MAPKs) mediated phosphorylation of BCL-6, followed by its ubiquitination and subsequent proteasomal degradation $5,25,31$. Down-regulation of BCL-6, in turn, restores DNA-damage responses, arrests proliferation, and allows for the expression of positiveregulatory-domain-containing 1 (PRDM1/ BLIMP1) a transcription factor required for plasma cell differentiation ${ }^{18,23}$.

All B-cell NHLs -with the exception of mantle-cell and lymphoblastic lymphoma - derive from either GC-cells or B-cells that have passed through the GC, as indicated by the fact that these lymphomas carry hypermutated $\mathrm{IgV}$ genes ${ }^{32}$. In addition, two main mechanisms of genetic lesion in B-NHL, i.e. chromosomal translocations and aberrant somatic hypermutation (ASHM), occur as byproducts of AID-dependent DNA remodeling events that take place in the GC. The requirement for AID in GC-derived lymphomagenesis was 
recently confirmed by the analyses of transgenic mice where it was shown that GC-derived lymphomas do not develop in animals lacking AID ${ }^{33}$.

\section{Diffuse large B-cell lymphoma subtypes derive from distinct B-cell differentiation stages}

DLBCL is remarkably diverse in both clinical presentation and outcome, likely reflecting its pathogenetic and biologic heterogeneity. Over the past decade, the usage of genome-wide expression profiling has not only allowed a better understanding of the molecular mechanisms underlying the development of this disease, but has also revealed a number of features associated with an unfavorable clinical outcome ${ }^{2,34-38}$. According to similarities to the putative cell of origin, DLBCL can be divided into at least three different groups: i) germinal center B-cell like (GCB) DLBCL, which derives from centroblasts, ii) activated Bcell like (ABC) DLBCL, which resembles features of plasmablastic B-cells committed to terminal B cell differentiation, and iii) primary mediastinal large B-cell lymphoma (PMBCL), presumably arising from thymic B-cells $36,39-40$. However, $15-30 \%$ of DLBCL cannot be classified into any of the above subgroups ${ }^{2,41}$. The cell-of-origin based classification has prognostic value, since ABC-DLBCL have a worse overall survival as compared to GCB-DLBCL, and respond less effectively to current therapeutic regimes, with cure rates of around $40 \%{ }^{35,42}$. Immunohistochemical markers have been shown to be able to discriminate the individual subgroups, and several of them -CD10, BCL-6, MUM1, BCL-2 and CYCLIN D2 - have been shown to be predictive of survival ${ }^{40,43}$. The combination of CD10, MUM1 and BCL-6 can divide DLBCL in GCB-DLBCL and nonGCB-DLBCL with about $80 \%$ concordance with the GEP ${ }^{40}$. A combination of 5 makers GCTE1, CD10, BCL-6, MUM1 and FOXP1- can achieve about 90\% concordance with the GEP ${ }^{44}$. In addition to the difference in cell of origin, these subgroups are associated with diverse genetic alterations (see below), suggesting that they depend on distinct oncogenic programs.

A separate classification scheme using gene-set enrichment analyses identified three phenotypic subsets characterized by the expression of genes involved in oxidative phosphorylation (OxPhos), B-cell receptor signaling (BCR) and host inflammatory response (HR) ${ }^{37}$. Tumors in the latter subset show increased expression of macrophage/dendritic cell markers, T/natural killer cell receptor and activation pathway components, as well as complement cascade members, and inflammatory mediators, suggesting an increased inflammatory response ${ }^{37}$. In HR tumors an increased number of infiltrating T cells and dendritic cells was found. Despite the increased immune response, these tumors do not have a favorable clinical outcome ${ }^{37}$.

\section{Mechanisms of genetic alteration in DLBCL}

Genetic alterations found in NHLs and in DLBCL in particular, include chromosomal translocations, mutations caused by ASHM, sporadic somatic mutations and copy number alterations, denoted by deletions and amplifications.

Chromosomal translocations in NHLs represent reciprocal and balanced recombination events frequently but not exclusively involving the immunoglobulin locus, with the breakpoint either located in the switch region or in the target region of SHM ${ }^{45-46}$. With very few exceptions, NHL-associated translocations do not lead to gene fusions, but cause dysregulated expression of the target gene. Given its critical function in both CSR and SHM, AID has been suggested to contribute to B-cell lymphomagenesis by facilitating the occurrence of chromosomal translocations and ASHM. Indeed, a direct role for AID in the development of GC-derived lymphomas has been demonstrated in mice ${ }^{33,47}$. 
The term ASHM defines a mechanism of genetic lesion resulting from the aberrant activity of the physiologic SHM machinery, as strongly suggested by the features of the observed mutations - specifically, the pattern of nucleotide exchanges, the requirement of transcription, and the distribution within $2 \mathrm{~kb}$ from the transcription initiation site ${ }^{48}$. By introducing mutations in the $5^{\prime}$ regulatory region of multiple genes, including coding sequences, ASHM is believed to play a major role in lymphomagenesis by causing deregulated expression of the target genes (often represented by proto-oncogenes) or by altering their protein function $48,49,50$. ASHM is primarily found in DLBCL, with more than $50 \%$ of cases affected ${ }^{48,51}$. Among the target genes identified so far are the well known proto-oncogenes MYC and PIM1 48.

In addition to chromosomal translocations and ASHM, altered gene expression in DLBCL can be caused by copy number alterations or somatic point mutations, analogous to nonlymphoid tumors. With the advent of novel techniques such as genome wide SNP array analysis and next-generation whole exome/genome sequencing analysis, novel lesions are likely to be identified. Recent examples include mutations and deletions of CREBBP and EP300, which are result in defective histone and non-histone protein acetylation in a significant fraction of DLBCL and FL (see below) ${ }^{52}$.

\section{Genetic Lesions associated with GCB-DLBCL}

The gene expression pattern of GCB-DLBCL is similar to that of normal GC-B-cells ${ }^{2}$. In addition, these tumors retain typical features of normal GC-B-cells such as CSR and SHM ${ }^{53}$. GCB-DLBCLs are characterized by several, different genetic alterations (Tab. 1).

In approximately $35 \%$ of cases, the translocation $\mathrm{t}(14 ; 18)$ leads to the ectopic expression of the B-cell lymphoma 2 (BCL-2) oncogene, a key anti-apoptotic molecule also expressed in follicular lymphoma (FL) and chronic lymphocytic leukemia ${ }^{54}$. BCL-2 translocations deregulate BCL-2 by juxtaposing potent regulatory elements from the Ig locus in close proximity to the BCL-2 locus, as well as by disrupting negative suppression by BCL- $6{ }^{16,20}$. Additionally, about $40 \%$ of DLBCL cases without a $t(14 ; 18)$ translocation co-express BCL-2 and BCL-6 as the results of several mechanisms including i) deregulation of Miz1, the coactiator molecule by which BCL- 6 binds to the BCL-2 promoter; i) ASHM of BCL-2 promoter sequences, iii) mutations in the BCL-2 coding sequence ${ }^{16}$. Increased levels of BCL-2 have been associated with an inferior outcome in DLBCL ${ }^{55-56 .}$

In 15\% of DLBCL, the MYC gene, encoding for a transcription factor associated with Burkitt lymphoma, is deregulated due to chromosomal translocations -most commonly $t(8 ; 14)^{55}$ - which bring the MYC coding sequence under the control of the immunoglobulin promoter ${ }^{57}$. Amplifications of the MIGH1 region containing the microRNA (miR) 17-92 cluster on chromosome $13 \mathrm{q}$ are found in around $12 \%$ of GCB-DLBCL ${ }^{58}$. This microRNA polycistron acts as a potential oncogene and accelerates MYC-induced lymphomagenesis in mice ${ }^{59-60}$. Furthermore, the cluster enhances oncogenesis by increasing proliferation and survival via inhibition of the tumor suppressor PTEN and the pro-apoptotic protein BIM ${ }^{60}$. Interestingly, deletions of PTEN on chromosome 10q, which are found in around $11 \%$ of cases and lead to the activation of AKT, are more frequent in GCB-DLBCL than ABCDLBCL, and are mutually exclusive to amplifications involving the miR-17-92-cluster ${ }^{58,61}$. Activation of phosphatidylinositol 3 kinase (PI3K) activates AKT and other pathways that inhibit apoptosis, promote cellular growth, cell motility and angiogenesis. Activating Mutations in PI3K are found in about $8 \%$ of DLBCL and are mutually exclusive with loss of PTEN ${ }^{62}$.

A number of chromatin modifying genes have been reported to be mutated in DLBCL with a prevalence in GCB-DLBCL. Recurrent somatic mutations affecting a single residue in the 
polycomb-group oncogene EZH2 have been found in $21.7 \%$ of GCB-DLBCL ${ }^{63}$. EZH2 is part of the Polycomb Repressive Complex and encodes for a histone methyltransferase trimethylating Lys 27 of histone H3. The identified mutations result in the replacement of a single tyrosine within the gene Set domain and have been recently shown to enhance the ability of EZH2 to trimethylate histone $\mathrm{H} 3$, in part by increasing its affinity for the substrate ${ }^{63-65}$. The histone methyltransferase MLL2 is somatically mutated in around $30 \%$ of DLBCL. The majority of the mutations introduce premature stop codons and frame-shift insertions and deletions that most likely inactivate MLL2 ${ }^{66-67}$ (and unpublished data). Myocyte enhancer factor 2B (MEF2B) is a member of the MADS/MEF2 family of DNA binding proteins which cooperates with histone modifying enzymes to regulate expression of genes. MEF2B is mutated in about $9 \%$ of DLBCL ${ }^{66-67}$ (and unpublished data). A recent study has identified monoallelic deletions and mutations inactivating CREBBP and EP300 in nearly $39 \%$ of GCB-DLBCL and less frequently in ABC-DLBCL (17\% of samples) ${ }^{52}$. CREBBP and EP300 are acetyltransferases that act as transcriptional co-activators in multiple signaling pathways. As a consequence of the mutations, CREBBP/EP300 lose their ability to acetylate BCL-6 and p53, a post-translational modification that inactivates BCL-6 by disrupting the recruitment of histone deacetylases (HDACs) and thus hindering its capacity to repress transcription, while representing an essential requirement for p53 activation ${ }^{68-69}$. Thus, CREBBP and EP300 mutations may contribute to lymphomagenesis by favoring the decreased activity of the tumor suppressor and constitutive activation of the oncogene ${ }^{52}$. Interestingly, these mutations are also found in about $40 \%$ of follicular lymphoma, suggesting that DLBCL and FL share common pathogenetic events 52 .

Mutations of $\mathrm{p} 53$ have been associated with transformation from follicular lymphoma, and should thus be more frequent in GCB-DLBCL, although conflicting results have been reported in other series. Nevertheless, p53 mutations were able to stratify GCB-DLBCL patients in subgroups with different survival ${ }^{70-72}$.

Mutations of the BCL- $65^{\prime}$ regulatory region are found in about $75 \%$ of all DLBCL, and reflect the activity of the physiologic SHM mechanism operating in GC B-cells ${ }^{7-8}$. However, a subset of these mutations affecting the gene $5^{\prime}$ untranslated exon 1 were exclusively found in DLBCL - particularly, in GCB-DLBCL - where they impair a negative autoregulatory loop through which BCL-6 controls its own expression ${ }^{49,73}$.

Evidence of ASHM is found in GCB-DLBCL as well as in ABC-DLBCL, overall accounting for more than $50 \%$ of DLBCL patients ${ }^{50-51}$. However, different mutation frequencies have been observed at certain target genes in the two DLBCL phenotypic subtypes. MYC and BCL-2 are preferentially targeted by ASHM in GCB-DLBCL ${ }^{16}$.

\section{Genetic Lesions associated with ABC-DLBCL}

The ABC subtype of DLBCL has a gene expression pattern that is similar to normal B-cells activated by BCR cross-linking in vitro and to a subset of GC B cells committed to plasma cell differentiation ${ }^{2}$. A prominent feature of the ABC-DLBCL gene expression signature is the enrichment in NF- $\mathrm{KB}$ target genes, suggesting that constitutive activation of NF- $\mathrm{\kappa B}$ plays an important role in this disease subtype ${ }^{74-75}$. Indeed, ABC-DLBCL cell lines are specifically dependent on NF- $\kappa B$ activity, as interference with NF- $\kappa$ B signaling kills ABCbut not GCB-DLBCL, and the NF-kB transcription complex is found in the nuclei of the tumor cells in a large fraction of cases ${ }^{74,76}$. Constitutive NF- $\mathrm{\kappa B}$ activation can be due to several distinct genetic alterations, which affect both positive and negative regulators of the pathway predominantly in ABC-DLBCL (Fig. 2 and Tab. 1) ${ }^{75,77-79}$. One of the most commonly involved genes is TNFAIP3, encoding for the negative NF- $\kappa \mathrm{B}$ regulator A20, with about $30 \%$ of cases displaying biallelic inactivation by mutations and/or deletions ${ }^{77}$. 
A20 is a dual-function ubiquitin-modifying enzyme involved in termination of NF- $\kappa \mathrm{B}$ responses ${ }^{80}$. Consistently, enforced expression of A20 in DLBCL cell lines carrying biallelic TNFAIP3 inactivation induced cell growth arrest and apoptosis by blocking NF- $\kappa \mathrm{B}$ signaling, as demonstrated by the cytoplasmic relocation of $\mathrm{p} 50^{77,81}$. Genetic alterations of A20 are also present in other lymphomas characterized by constitutive NF- $\mathrm{\kappa B}$ activation (e.g. marginal zone lymphoma, Hodgkin lymphoma), while they are rarely found in GCBDLBCL $77,81-83$.

In normal B-cells, BCR induced activation of NF- $\mathrm{KB}$ requires CARD11, a scaffold protein that coordinates the activation of I $x B$ kinase $\beta^{84}$. Mutations of CARD11 are found in around $10 \%$ of ABC-DLBCL as well as in a smaller subset of GCB-DLBCL, and typically affect amino acids within or adjacent to the coiled-coil domain ${ }^{77,85}$. Introduction of CARD11 mutants into lymphoma cell lines leads to constitutive NF- $\kappa$ B activation, suggesting that lymphoma cells with CARD11 mutations are engaging the NF- $\mathrm{KB}$ pathway in the absence of BCR signaling ${ }^{85}$. CD79A and CD79B are proximal BCR subunits and were found to be mutated in around $20 \%$ of ABC-DLBCL ${ }^{74}$. The mutations target the immunoreceptor tyrosine-based activation motif (ITAM) of CD79A and CD79B, most frequently at a conserved tyrosine residue, thus increasing surface BCR expression and attenuating a feedback inhibitor of BCR signaling ${ }^{74}$. Overall, CD79A and CD79B mutations are thought to induce chronic active BCR signaling, with consequent activation of NF- $\ltimes$ B, PI3K and MAP-kinase pathways.

During the normal immune response, NF- $\kappa \mathrm{B}$ is also activated after stimulation of TLRs and receptors for interleukin (IL) 1 and $8^{86-87}$. MYD88 functions as a signaling adaptor protein, coordinating the assembly of a complex that activates NF- $\kappa$ B following TLRs and IL-1 and IL8 receptors stimulation ${ }^{86-87}$. MYD88 mutations are found in about 30\% of ABC-DLBCL, harboring the same amino acid substitution (L265P) in the Toll/IL-1 receptor domain ${ }^{78}$. The L265P mutant protein may promote cell survival by activating NF- $\mathrm{kB}$-signalling, JAK kinase activation of STAT3, and secretion of IL-6, IL-10 and INF $\beta^{78}$.

Other mutations affecting NF- $\kappa$ B modulators in DLBCLs include TRAF2 (3\%), TRAF5 $(5 \%)$, MAP3K7 (5\%) and RANK (8\%) ${ }^{77}$. A TRAF2 mutant isolated from an ABC-DLBCL was able to activate NF- $\mathrm{kB}$, while the functional consequences of the remaining mutations have not been studied in detail ${ }^{77}$.

Consistent with these findings, treatment with the proteasome inhibitor Bortezomib, which blocks the degradation of I $\mathrm{KBa}$, leads to significantly higher response rates in ABC-DLBCL patients 88 .

Normal GC-B-cells require the down regulation of BCL- 6 - mediated by NF-kB - and expression of IRF4, BLIMP1 and XBP1 for plasma cell differentiation ${ }^{17-18,24}$. In ABCDLBCL, several lesions involving this pathway have been found. Chromosomal translocations of BCL-6, located on chromosome 3q27, are detected in about $35 \%$ of cases, with a two-fold higher incidence in ABC-DLBCL as compared to GCB-DLBCL 73,89-91. The translocations are balanced, reciprocal and involve various alternative partners ${ }^{12,91-94}$. Most of the translocations result in a fusion transcript, with the promoter region and the first non-coding exon of BCL- 6 being replaced by the translocation partner ${ }^{95-96}$. The most common translocations involve the immunoglobulin heavy-chain promoter, resulting in constitutive expression of BCL- $6{ }^{12,91}$. Deregulated expression of BCL-6 is thought to play a critical role in blocking differentiation, decreasing the p53-mediated apoptotic response to DNA damage as well as providing a proliferative advantage $14-15,17-20$. This is supported by the fact that mice with deregulated BCL-6 expression develop DLBCL ${ }^{97}$. 
The PRDM1 gene - located on chromosome 6q21 - encodes for BLMP1, a zinc finger transcriptional repressor. BLIMP1 is essential for the differentiation of B-cells into plasma cells ${ }^{98-100}$, which it promotes in part by repressing genes involved in BCR signaling and proliferation 101-102. Inactivating mutations and deletions of PRDM1 are found in up to $30 \%$ of ABC-DLBCL ${ }^{103-106}$. Additionally, BLIMP1 can be inactivated by transcriptional repression through constitutively active BCL-6, as it is the case in patients carrying BCL-6 translocations. Consistent with this model, chromosomal transloactions of BCL-6 and genetic alterations affecting BLIMP1 are mutually exclusive ${ }^{103-105}$. Notably, the remaining over 30\% of ABC-DLBCL lack BLIMP1 protein despite the expression of IRF4 and the absence of genetic alterations in BLIMP1 or BCL-6 ${ }^{105}$. Since IRF4 is invariably coexpressed with BLIMP1 in plasma cells and differentiating GC-B-cells, these observations suggest that alternative mechanisms exist to inactivate BLIMP1 in ABC-DLBCL. The role of BLIMP1 as a tumor suppressor has been recently demonstrated in a mouse model where conditional deletion of the gene leads to the development of lymphoproliferative disorders recapitulating features of ABC-DLBCL ${ }^{105-106}$.

Amplifications of the telomeric segment of chromosome 19q are found in about $25 \%$ of ABC-DLBCL ${ }^{58}$. SPIB - an ETS family transcription factor - is supposed to be one functionally important gene on chromosome $19 \mathrm{q}$, a model supported by the fact that down regulation of SPIB was toxic to ABC-DLBCL cell lines ${ }^{58}$. In addition, a translocation between SPIB and the Ig heavy chain locus was found in one ABC-DLBCL cell line ${ }^{46}$.

Homozygous or heterozygous deletions of the INK4a/ARF locus are observed in about $30 \%$ of $\mathrm{ABC}-\mathrm{DLBCL}{ }^{58}$. P16 ${ }^{\mathrm{INK} 4 \mathrm{a}}$ and $\mathrm{p} 14^{\mathrm{ARF}}$ regulate the $\mathrm{pRB}$ and the $\mathrm{p} 53$ tumor suppressor pathways, and inactivation of the p53 pathway via INK4a/ARF is found to inhibit apoptosis in aggressive lymphoid malignancies ${ }^{107-108}$.

\section{Genetic Lesions associated with PMBCL}

Primary mediastinal large B-cell lymphoma (PMBCL) accounts for less than 3\% of NHLs and is a tumor of young adults with a median age of about 35 years ${ }^{109-110}$, and females being affected more frequently than men ${ }^{111}$. The only site of lymphoma involvement is the anterior mediastinum, but the rapidly growing bulky tumor can extend locally into other thoracic structures ${ }^{112}$. This distinctive location, together with its gene expression profile, suggest that this DLBCL subtype arises from thymic B-cells in the mediastinum 111,113-114. PMBCL are characterized by several genetic alterations (Tab. 1). A common lesion in PMBCL is represented by gains of band 9 p 24 , found in about $70 \%$ of the cases $115-117$. The amplified region contains several genes of possible pathogenetic significance, including the gene encoding for the tyrosine kinase JAK2 and the PDL1 and PDL2 loci, which are regulators of T-cell responses. These three genes were all expressed at high levels in PMBCL as compared to other DLBCL subtypes ${ }^{38}$. Recently PDL1 and PDL2 have been identified as key targets of these amplifications using high-resolution copy number data ${ }^{118}$. Overexpression of JAK2 was proposed to be responsible for the constitutive activation of the transcription factor STAT6, due to its ability to activate IL-3 and IL-4, which are both involved in the regulation of STAT6 ${ }^{36,119}$. Moreover, SOCS1, a negative regulator of JAK2, is commonly affected by genetic lesions in PMBCL ${ }^{120-121}$.

PMBCL also shares with ABC-DLBCL the evidence of NF- $\mathrm{KB}$ pathway constitutive actiation, with PMBCL expressing increased levels of NF- $\kappa \mathrm{B}$ targets that promote cell survival and inhibit apoptosis ${ }^{122}$. Gains of chromosome 2 p14-16 encompassing the NF- $\kappa B$ family member REL, are found in about 70\% PMBCL and include 115,117 . Also affected by these gains is BCL11A, a transcriptional repressor that may provide a survival advantage ${ }^{117}$. 
Interestingly PMBCL and classic Hodgkin's lymphoma have a notable genomic similarity, including gains on $2 p$ and $9 p^{123}$. Furthermore, remarkable similarities in the gene expression profiles of these two diseases have been found ${ }^{36,38}$. However, the gene expression signature of PMBCL retains the expression of genes typical of mature B-cells, while these transcripts are shut down in Hodgkin's lymphoma.

\section{Concluding remarks}

Within recent years our understanding of the pathogenesis of DLBCL has significantly improved. Genome-wide expression profiling has illustrated the heterogeneity of DLBCL and allowed a better understanding of the molecular mechanisms underlying the disease. The known genetic lesions do not account for all DLBCL cases and therefore only represent a subset of those required for tumor initiation. New techniques like whole genome/exome sequencing and genome-wide SNP analyses have already led to the identification of novel genetically altered genes in DLBCL and further improved our understanding of the disease. Identification of tumors that are dependent on particular signaling pathways is essential to improve disease stratification and will provide more effective and less toxic targeted therapy approaches.

\section{References}

1. Campo E, et al. The 2008 WHO classification of lymphoid neoplasms and beyond: evolving concepts and practical applications. Blood. 2011

2. Alizadeh AA, et al. Distinct types of diffuse large B-cell lymphoma identified by gene expression profiling. Nature. 2000; 403:503-511. [PubMed: 10676951]

3. Jacob J, Kelsoe G, Rajewsky K, Weiss U. Intraclonal generation of antibody mutants in germinal centres. Nature. 1991; 354:389-392. [PubMed: 1956400]

4. Berek C, Berger A, Apel M. Maturation of the immune response in germinal centers. Cell. 1991; 67:1121-1129. [PubMed: 1760840]

5. Rajewsky K. Clonal selection and learning in the antibody system. Nature. 1996; 381:751-758. [PubMed: 8657279]

6. Shen HM, Peters A, Baron B, Zhu X, Storb U. Mutation of BCL-6 gene in normal B cells by the process of somatic hypermutation of Ig genes. Science. 1998; 280:1750-1752. [PubMed: 9624052]

7. Pasqualucci L, et al. BCL-6 mutations in normal germinal center B cells: evidence of somatic hypermutation acting outside Ig loci. Proc Natl Acad Sci U S A. 1998; 95:11816-11821. [PubMed: 9751748]

8. Migliazza A, et al. Frequent somatic hypermutation of the $5^{\prime}$ noncoding region of the BCL6 gene in B-cell lymphoma. Proc Natl Acad Sci U S A. 1995; 92:12520-12524. [PubMed: 8618933]

9. Petersen-Mahrt SK, Harris RS, Neuberger MS. AID mutates E. coli suggesting a DNA deamination mechanism for antibody diversification. Nature. 2002; 418:99-103. [PubMed: 12097915]

10. Bransteitter R, Pham P, Scharff MD, Goodman MF. Activation-induced cytidine deaminase deaminates deoxycytidine on single-stranded DNA but requires the action of RNase. Proc Natl Acad Sci U S A. 2003; 100:4102-4107. [PubMed: 12651944]

11. Chaudhuri J, et al. Transcription-targeted DNA deamination by the AID antibody diversification enzyme. Nature. 2003; 422:726-730. [PubMed: 12692563]

12. Ye BH, Rao PH, Chaganti RS, Dalla-Favera R. Cloning of bcl-6, the locus involved in chromosome translocations affecting band 3q27 in B-cell lymphoma. Cancer Res. 1993; 53:27322735. [PubMed: 8504412]

13. Ye BH, et al. The BCL-6 proto-oncogene controls germinal-centre formation and Th2-type inflammation. Nat Genet. 1997; 16:161-170. [PubMed: 9171827]

14. Basso K, et al. Integrated biochemical and computational approach identifies BCL6 direct target genes controlling multiple pathways in normal germinal center B cells. Blood. 2010; 115:975-984. [PubMed: 19965633] 
15. Phan RT, Dalla-Favera R. The BCL6 proto-oncogene suppresses p53 expression in germinalcentre B cells. Nature. 2004; 432:635-639. [PubMed: 15577913]

16. Saito M, et al. BCL6 suppression of BCL2 via Miz1 and its disruption in diffuse large B cell lymphoma. Proc Natl Acad Sci U S A. 2009; 106:11294-11299. [PubMed: 19549844]

17. Shaffer AL, et al. BCL-6 represses genes that function in lymphocyte differentiation, inflammation, and cell cycle control. Immunity. 2000; 13:199-212. [PubMed: 10981963]

18. Tunyaplin C, et al. Direct repression of prdm1 by Bcl-6 inhibits plasmacytic differentiation. $\mathbf{J}$ Immunol. 2004; 173:1158-1165. [PubMed: 15240705]

19. Phan RT, Saito M, Basso K, Niu H, Dalla-Favera R. BCL6 interacts with the transcription factor Miz-1 to suppress the cyclin-dependent kinase inhibitor p21 and cell cycle arrest in germinal center B cells. Nat Immunol. 2005; 6:1054-1060. [PubMed: 16142238]

20. Ci W, et al. The BCL6 transcriptional program features repression of multiple oncogenes in primary B cells and is deregulated in DLBCL. Blood. 2009; 113:5536-5548. [PubMed: 19307668]

21. Niu H, Cattoretti G, Dalla-Favera R. BCL6 controls the expression of the B7-1/CD80 costimulatory receptor in germinal center B cells. J Exp Med. 2003; 198:211-221. [PubMed: 12860928]

22. Ranuncolo SM, et al. Bcl-6 mediates the germinal center B cell phenotype and lymphomagenesis through transcriptional repression of the DNA-damage sensor ATR. Nat Immunol. 2007; 8:705714. [PubMed: 17558410]

23. Turner CA Jr. Mack DH, Davis MM. Blimp-1, a novel zinc finger-containing protein that can drive the maturation of B lymphocytes into immunoglobulin-secreting cells. Cell. 1994; 77:297-306. [PubMed: 8168136]

24. Klein U, et al. Transcription factor IRF4 controls plasma cell differentiation and class-switch recombination. Nat Immunol. 2006; 7:773-782. [PubMed: 16767092]

25. Klein U, Dalla-Favera R. Germinal centres: role in B-cell physiology and malignancy. Nat Rev Immunol. 2008; 8:22-33. [PubMed: 18097447]

26. Liu YJ, et al. Sequential triggering of apoptosis, somatic mutation and isotype switch during germinal center development. Semin Immunol. 1996; 8:169-177. [PubMed: 8738916]

27. Muramatsu M, et al. Class switch recombination and hypermutation require activation-induced cytidine deaminase (AID), a potential RNA editing enzyme. Cell. 2000; 102:553-563. [PubMed: 11007474]

28. Revy P, et al. Activation-induced cytidine deaminase (AID) deficiency causes the autosomal recessive form of the Hyper-IgM syndrome (HIGM2). Cell. 2000; 102:565-575. [PubMed: 11007475]

29. Allman D, et al. BCL-6 expression during B-cell activation. Blood. 1996; 87:5257-5268. [PubMed: 8652841]

30. Saito M, et al. A signaling pathway mediating downregulation of BCL6 in germinal center B cells is blocked by BCL6 gene alterations in B cell lymphoma. Cancer Cell. 2007; 12:280-292. [PubMed: 17785208]

31. Niu H, Ye BH, Dalla-Favera R. Antigen receptor signaling induces MAP kinase-mediated phosphorylation and degradation of the BCL-6 transcription factor. Genes Dev. 1998; 12:19531961. [PubMed: 9649500]

32. Kuppers R, Klein U, Hansmann ML, Rajewsky K. Cellular origin of human B-cell lymphomas. N Engl J Med. 1999; 341:1520-1529. [PubMed: 10559454]

33. Pasqualucci L, et al. AID is required for germinal center-derived lymphomagenesis. Nat Genet. 2008; 40:108-112. [PubMed: 18066064]

34. Shipp MA, et al. Diffuse large B-cell lymphoma outcome prediction by gene-expression profiling and supervised machine learning. Nat Med. 2002; 8:68-74. [PubMed: 11786909]

35. Rosenwald A, et al. The use of molecular profiling to predict survival after chemotherapy for diffuse large-B-cell lymphoma. N Engl J Med. 2002; 346:1937-1947. [PubMed: 12075054]

36. Savage KJ, et al. The molecular signature of mediastinal large B-cell lymphoma differs from that of other diffuse large B-cell lymphomas and shares features with classical Hodgkin lymphoma. Blood. 2003; 102:3871-3879. [PubMed: 12933571] 
37. Monti S, et al. Molecular profiling of diffuse large B-cell lymphoma identifies robust subtypes including one characterized by host inflammatory response. Blood. 2005; 105:1851-1861. [PubMed: 15550490]

38. Rosenwald A, et al. Molecular diagnosis of primary mediastinal B cell lymphoma identifies a clinically favorable subgroup of diffuse large B cell lymphoma related to Hodgkin lymphoma. J Exp Med. 2003; 198:851-862. [PubMed: 12975453]

39. Alizadeh AA, Gentles AJ, Lossos IS, Levy R. Molecular outcome prediction in diffuse large-B-cell lymphoma. N Engl J Med. 2009; 360:2794-2795. [PubMed: 19553658]

40. Hans CP, et al. Confirmation of the molecular classification of diffuse large B-cell lymphoma by immunohistochemistry using a tissue microarray. Blood. 2004; 103:275-282. [PubMed: 14504078]

41. Wright $\mathrm{G}$, et al. A gene expression-based method to diagnose clinically distinct subgroups of diffuse large B cell lymphoma. Proc Natl Acad Sci U S A. 2003; 100:9991-9996. [PubMed: 12900505]

42. Lenz G, et al. Stromal gene signatures in large-B-cell lymphomas. N Engl J Med. 2008; 359:23132323. [PubMed: 19038878]

43. Chang CC, et al. Immunohistochemical expression patterns of germinal center and activation Bcell markers correlate with prognosis in diffuse large B-cell lymphoma. Am J Surg Pathol. 2004; 28:464-470. [PubMed: 15087665]

44. Choi WW, et al. A new immunostain algorithm classifies diffuse large B-cell lymphoma into molecular subtypes with high accuracy. Clin Cancer Res. 2009; 15:5494-5502. [PubMed: 19706817]

45. Kuppers R, Dalla-Favera R. Mechanisms of chromosomal translocations in B cell lymphomas. Oncogene. 2001; 20:5580-5594. [PubMed: 11607811]

46. Lenz G, et al. Aberrant immunoglobulin class switch recombination and switch translocations in activated B cell-like diffuse large B cell lymphoma. J Exp Med. 2007; 204:633-643. [PubMed: 17353367]

47. Ramiro AR, et al. AID is required for c-myc/IgH chromosome translocations in vivo. Cell. 2004; 118:431-438. [PubMed: 15315756]

48. Pasqualucci L, et al. Hypermutation of multiple proto-oncogenes in B-cell diffuse large-cell lymphomas. Nature. 2001; 412:341-346. [PubMed: 11460166]

49. Pasqualucci L, et al. Mutations of the BCL6 proto-oncogene disrupt its negative autoregulation in diffuse large B-cell lymphoma. Blood. 2003; 101:2914-2923. [PubMed: 12515714]

50. Wang X, Li Z, Naganuma A, Ye BH. Negative autoregulation of BCL-6 is bypassed by genetic alterations in diffuse large B cell lymphomas. Proc Natl Acad Sci U S A. 2002; 99:15018-15023. [PubMed: 12407182]

51. Montesinos-Rongen M, Van Roost D, Schaller C, Wiestler OD, Deckert M. Primary diffuse large B-cell lymphomas of the central nervous system are targeted by aberrant somatic hypermutation. Blood. 2004; 103:1869-1875. [PubMed: 14592832]

52. Pasqualucci L, et al. Inactivating mutations of acetyltransferase genes in B-cell lymphoma. Nature. 2011; 471:189-195. [PubMed: 21390126]

53. Lossos IS, et al. Ongoing immunoglobulin somatic mutation in germinal center B cell-like but not in activated B cell-like diffuse large cell lymphomas. Proc Natl Acad Sci U S A. 2000; 97:1020910213. [PubMed: 10954754]

54. Weiss LM, Warnke RA, Sklar J, Cleary ML. Molecular analysis of the $t(14 ; 18)$ chromosomal translocation in malignant lymphomas. N Engl J Med. 1987; 317:1185-1189. [PubMed: 3657890]

55. Kramer MH, et al. Clinical relevance of BCL2, BCL6, and MYC rearrangements in diffuse large B-cell lymphoma. Blood. 1998; 92:3152-3162. [PubMed: 9787151]

56. Gascoyne RD, et al. Prognostic significance of Bcl-2 protein expression and $\mathrm{Bcl}-2$ gene rearrangement in diffuse aggressive non-Hodgkin's lymphoma. Blood. 1997; 90:244-251. [PubMed: 9207459]

57. Ladanyi M, Offit K, Jhanwar SC, Filippa DA, Chaganti RS. MYC rearrangement and translocations involving band 8q24 in diffuse large cell lymphomas. Blood. 1991; 77:1057-1063. [PubMed: 1671647] 
58. Lenz G, et al. Molecular subtypes of diffuse large B-cell lymphoma arise by distinct genetic pathways. Proc Natl Acad Sci U S A. 2008; 105:13520-13525. [PubMed: 18765795]

59. He L, et al. A microRNA polycistron as a potential human oncogene. Nature. $2005 ; 435: 828-833$. [PubMed: 15944707]

60. Xiao C, et al. Lymphoproliferative disease and autoimmunity in mice with increased miR-17-92 expression in lymphocytes. Nat Immunol. 2008; 9:405-414. [PubMed: 18327259]

61. Chan WJ. Pathogenesis of diffuse large B cell lymphoma. Int J Hematol. 2010; 92:219-230. [PubMed: 20582737]

62. Abubaker J, et al. PIK3CA mutations are mutually exclusive with PTEN loss in diffuse large Bcell lymphoma. Leukemia. 2007; 21:2368-2370. [PubMed: 17657213]

63. Morin RD, et al. Somatic mutations altering EZH2 (Tyr641) in follicular and diffuse large B-cell lymphomas of germinal-center origin. Nat Genet. 2010; 42:181-185. [PubMed: 20081860]

64. Sneeringer CJ, et al. Coordinated activities of wild-type plus mutant EZH2 drive tumor-associated hypertrimethylation of lysine 27 on histone H3 (H3K27) in human B-cell lymphomas. Proc Natl Acad Sci U S A. 2010; 107:20980-20985. [PubMed: 21078963]

65. Yap DB, et al. Somatic mutations at EZH2 Y641 act dominantly through a mechanism of selectively altered PRC2 catalytic activity, to increase H3K27 trimethylation. Blood. 2011; 117:2451-2459. [PubMed: 21190999]

66. Morin RD. Identification of Genes Frequently Mutated in FL and DLBCL with Transcriptome, Genome and Exome Sequencing. Blood. 2010; 116:352.

67. Mendez-Lago M. Mutations In MLL2 and MEF2B Genes In Follicular Lymphoma and Diffuse Large B-Cell Lymphoma. Blood. 2010; 116:211.

68. Bereshchenko OR, Gu W, Dalla-Favera R. Acetylation inactivates the transcriptional repressor BCL6. Nat Genet. 2002; 32:606-613. [PubMed: 12402037]

69. Gu W, Roeder RG. Activation of p53 sequence-specific DNA binding by acetylation of the p53 Cterminal domain. Cell. 1997; 90:595-606. [PubMed: 9288740]

70. Lo Coco F, et al. p53 mutations are associated with histologic transformation of follicular lymphoma. Blood. 1993; 82:2289-2295. [PubMed: 8400281]

71. Young KH, et al. Mutations in the DNA-binding codons of TP53, which are associated with decreased expression of TRAILreceptor-2, predict for poor survival in diffuse large B-cell lymphoma. Blood. 2007; 110:4396-4405. [PubMed: 17881637]

72. Young KH, et al. Structural profiles of TP53 gene mutations predict clinical outcome in diffuse large B-cell lymphoma: an international collaborative study. Blood. 2008; 112:3088-3098. [PubMed: 18559976]

73. Iqbal J, et al. Distinctive patterns of BCL6 molecular alterations and their functional consequences in different subgroups of diffuse large B-cell lymphoma. Leukemia. 2007; 21:2332-2343. [PubMed: 17625604]

74. Davis RE, Brown KD, Siebenlist U, Staudt LM. Constitutive nuclear factor kappaB activity is required for survival of activated B cell-like diffuse large B cell lymphoma cells. J Exp Med. 2001; 194:1861-1874. [PubMed: 11748286]

75. Jost PJ, Ruland J. Aberrant NF-kappaB signaling in lymphoma: mechanisms, consequences, and therapeutic implications. Blood. 2007; 109:2700-2707. [PubMed: 17119127]

76. Lam LT, et al. Small molecule inhibitors of IkappaB kinase are selectively toxic for subgroups of diffuse large B-cell lymphoma defined by gene expression profiling. Clin Cancer Res. 2005; 11:28-40. [PubMed: 15671525]

77. Compagno M, et al. Mutations of multiple genes cause deregulation of NF-kappaB in diffuse large B-cell lymphoma. Nature. 2009; 459:717-721. [PubMed: 19412164]

78. Ngo VN, et al. Oncogenically active MYD88 mutations in human lymphoma. Nature. 2011; 470:115-119. [PubMed: 21179087]

79. Davis RE, et al. Chronic active B-cell-receptor signalling in diffuse large B-cell lymphoma. Nature. 2010; 463:88-92. [PubMed: 20054396]

80. Boone DL, et al. The ubiquitin-modifying enzyme A20 is required for termination of Toll-like receptor responses. Nat Immunol. 2004; 5:1052-1060. [PubMed: 15334086] 
81. Kato M, et al. Frequent inactivation of A20 in B-cell lymphomas. Nature. 2009; 459:712-716. [PubMed: 19412163]

82. Novak U, et al. The NF-\{kappa\}B negative regulator TNFAIP3 (A20) is inactivated by somatic mutations and genomic deletions in marginal zone lymphomas. Blood. 2009; 113:4918-4921. [PubMed: 19258598]

83. Schmitz R, et al. TNFAIP3 (A20) is a tumor suppressor gene in Hodgkin lymphoma and primary mediastinal B cell lymphoma. J Exp Med. 2009; 206:981-989. [PubMed: 19380639]

84. Rawlings DJ, Sommer K, Moreno-Garcia ME. The CARMA1 signalosome links the signalling machinery of adaptive and innate immunity in lymphocytes. Nat Rev Immunol. 2006; 6:799-812. [PubMed: 17063183]

85. Lenz G, et al. Oncogenic CARD11 mutations in human diffuse large B cell lymphoma. Science. 2008; 319:1676-1679. [PubMed: 18323416]

86. Lin SC, Lo YC, Wu H. Helical assembly in the MyD88-IRAK4-IRAK2 complex in TLR/IL-1R signalling. Nature. 2010; 465:885-890. [PubMed: 20485341]

87. Iwasaki A, Medzhitov R. Regulation of adaptive immunity by the innate immune system. Science. 2010; 327:291-295. [PubMed: 20075244]

88. Dunleavy K, et al. Differential efficacy of bortezomib plus chemotherapy within molecular subtypes of diffuse large B-cell lymphoma. Blood. 2009; 113:6069-6076. [PubMed: 19380866]

89. Offit K, et al. t(3;22)(q27;q11): a novel translocation associated with diffuse non-Hodgkin's lymphoma. Blood. 1989; 74:1876-1879. [PubMed: 2804338]

90. Lo Coco F, et al. Rearrangements of the BCL6 gene in diffuse large cell non-Hodgkin's lymphoma. Blood. 1994; 83:1757-1759. [PubMed: 8142643]

91. Ye BH, et al. Alterations of a zinc finger-encoding gene, BCL-6, in diffuse large-cell lymphoma. Science. 1993; 262:747-750. [PubMed: 8235596]

92. Kerckaert JP, et al. LAZ3, a novel zinc-finger encoding gene, is disrupted by recurring chromosome 3q27 translocations in human lymphomas. Nat Genet. 1993; 5:66-70. [PubMed: 8220427]

93. Baron BW, et al. Identification of the gene associated with the recurring chromosomal translocations t(3;14)(q27;q32) and t(3;22)(q27;q11) in B-cell lymphomas. Proc Natl Acad Sci U S A. 1993; 90:5262-5266. [PubMed: 8506375]

94. Miki T, et al. Molecular cloning of the breakpoint for 3q27 translocation in B-cell lymphomas and leukemias. Blood. 1994; 83:217-222. [PubMed: 8274736]

95. Ye BH, et al. Chromosomal translocations cause deregulated BCL6 expression by promoter substitution in B cell lymphoma. EMBO J. 1995; 14:6209-6217. [PubMed: 8557040]

96. Chen W, Iida S, Louie DC, Dalla-Favera R, Chaganti RS. Heterologous promoters fused to BCL6 by chromosomal translocations affecting band 3q27 cause its deregulated expression during B-cell differentiation. Blood. 1998; 91:603-607. [PubMed: 9427715]

97. Cattoretti G, et al. Deregulated BCL6 expression recapitulates the pathogenesis of human diffuse large B cell lymphomas in mice. Cancer Cell. 2005; 7:445-455. [PubMed: 15894265]

98. Cattoretti G, et al. PRDM1/Blimp-1 is expressed in human B-lymphocytes committed to the plasma cell lineage. J Pathol. 2005; 206:76-86. [PubMed: 15772984]

99. Shapiro-Shelef M, et al. Blimp-1 is required for the formation of immunoglobulin secreting plasma cells and pre-plasma memory B cells. Immunity. 2003; 19:607-620. [PubMed: 14563324]

100. Angelin-Duclos C, Cattoretti G, Lin KI, Calame K. Commitment of B lymphocytes to a plasma cell fate is associated with Blimp-1 expression in vivo. J Immunol. 2000; 165:5462-5471. [PubMed: 11067898]

101. Lin Y, Wong K, Calame K. Repression of c-myc transcription by Blimp-1, an inducer of terminal B cell differentiation. Science. 1997; 276:596-599. [PubMed: 9110979]

102. Shaffer AL, et al. Blimp-1 orchestrates plasma cell differentiation by extinguishing the mature B cell gene expression program. Immunity. 2002; 17:51-62. [PubMed: 12150891]

103. Pasqualucci L, et al. Inactivation of the PRDM1/BLIMP1 gene in diffuse large B cell lymphoma. J Exp Med. 2006; 203:311-317. [PubMed: 16492805] 
104. Tam W, et al. Mutational analysis of PRDM1 indicates a tumor-suppressor role in diffuse large B-cell lymphomas. Blood. 2006; 107:4090-4100. [PubMed: 16424392]

105. Mandelbaum J, et al. BLIMP1 is a tumor suppressor gene frequently disrupted in activated B celllike diffuse large B cell lymphoma. Cancer Cell. 2010; 18:568-579. [PubMed: 21156281]

106. Calado DP, et al. Constitutive canonical NF-kappaB activation cooperates with disruption of BLIMP1 in the pathogenesis of activated B cell-like diffuse large cell lymphoma. Cancer Cell. 2010; 18:580-589. [PubMed: 21156282]

107. Pinyol M, et al. p16(INK4a) gene inactivation by deletions, mutations, and hypermethylation is associated with transformed and aggressive variants of non-Hodgkin's lymphomas. Blood. 1998; 91:2977-2984. [PubMed: 9531609]

108. Pinyol M, et al. INK4a/ARF locus alterations in human non-Hodgkin's lymphomas mainly occur in tumors with wild-type p53 gene. Am J Pathol. 2000; 156:1987-1996. [PubMed: 10854221]

109. A clinical evaluation of the International Lymphoma Study Group classification of nonHodgkin's lymphoma. The Non-Hodgkin's Lymphoma Classification Project. Blood. 1997; 89:3909-3918. [PubMed: 9166827]

110. Savage KJ, et al. Favorable outcome of primary mediastinal large B-cell lymphoma in a single institution: the British Columbia experience. Ann Oncol. 2006; 17:123-130. [PubMed: 16236753]

111. Barth TF, Leithauser F, Joos S, Bentz M, Moller P. Mediastinal (thymic) large B-cell lymphoma: where do we stand? Lancet Oncol. 2002; 3:229-234. [PubMed: 12067685]

112. van Besien K, Kelta M, Bahaguna P. Primary mediastinal B-cell lymphoma: a review of pathology and management. J Clin Oncol. 2001; 19:1855-1864. [PubMed: 11251018]

113. Hofmann WJ, Momburg F, Moller P. Thymic medullary cells expressing B lymphocyte antigens. Hum Pathol. 1988; 19:1280-1287. [PubMed: 3263309]

114. Isaacson PG, Norton AJ, Addis BJ. The human thymus contains a novel population of B lymphocytes. Lancet. 1987; 2:1488-1491. [PubMed: 2447458]

115. Bentz M, et al. Gain of chromosome arm $9 \mathrm{p}$ is characteristic of primary mediastinal B-cell lymphoma (MBL): comprehensive molecular cytogenetic analysis and presentation of a novel MBL cell line. Genes Chromosomes Cancer. 2001; 30:393-401. [PubMed: 11241792]

116. Joos S, et al. Primary mediastinal (thymic) B-cell lymphoma is characterized by gains of chromosomal material including 9p and amplification of the REL gene. Blood. 1996; 87:15711578. [PubMed: 8608249]

117. Wessendorf $\mathrm{S}$, et al. Further delineation of chromosomal consensus regions in primary mediastinal B-cell lymphomas: an analysis of 37 tumor samples using high-resolution genomic profiling (array-CGH). Leukemia. 2007; 21:2463-2469. [PubMed: 17728785]

118. Green MR, et al. Integrative analysis reveals selective 9p24.1 amplification, increased PD-1 ligand expression, and further induction via JAK2 in nodular sclerosing Hodgkin lymphoma and primary mediastinal large B-cell lymphoma. Blood. 2010; 116:3268-3277. [PubMed: 20628145]

119. Guiter C, et al. Constitutive STAT6 activation in primary mediastinal large B-cell lymphoma. Blood. 2004; 104:543-549. [PubMed: 15044251]

120. Kimm LR, et al. Frequent occurrence of deletions in primary mediastinal B-cell lymphoma. Genes Chromosomes Cancer. 2007; 46:1090-1097. [PubMed: 17823928]

121. Mestre C, et al. Homozygous deletion of SOCS1 in primary mediastinal B-cell lymphoma detected by CGH to BAC microarrays. Leukemia. 2005; 19:1082-1084. [PubMed: 15815722]

122. Feuerhake F, et al. NFkappaB activity, function, and target-gene signatures in primary mediastinal large B-cell lymphoma and diffuse large B-cell lymphoma subtypes. Blood. 2005; 106:1392-1399. [PubMed: 15870177]

123. Joos S, et al. Genomic imbalances including amplification of the tyrosine kinase gene JAK2 in CD30+ Hodgkin cells. Cancer Res. 2000; 60:549-552. [PubMed: 10676635]

124. Monni O, Joensuu H, Franssila K, Klefstrom J, Alitalo K, Knuutila S. BCL2 overexpression associated with chromosomal amplification in diffuse large B-cell lymphoma. Blood. Aug 1; 1997 90(3):1168-74. [PubMed: 9242549]

125. Melzner I, Bucur AJ, Brüderlein S, Dorsch K, Hasel C, Barth TF, Leithäuser F, Möller P. Biallelic mutation of SOCS-1 impairs JAK2 degradation and sustains phospho-JAK2 action in 
the MedB-1 mediastinal lymphoma line. Blood. Mar 15; 2005 105(6):2535-42. [PubMed: 15572583] 


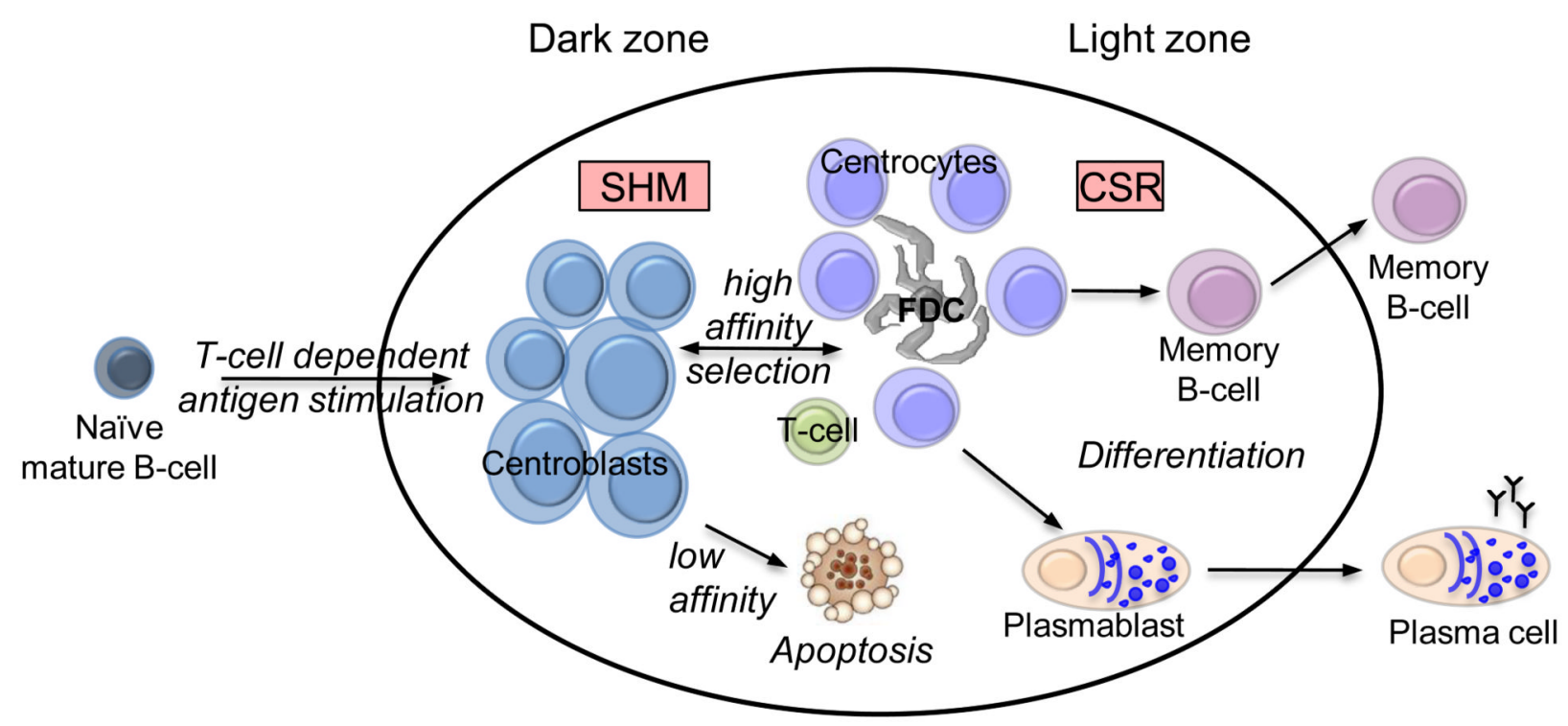

Figure 1.

The germinal center reaction

Upon T-cell dependent antigen stimulation, naïve B-cells migrate to secondary lymphoid organs, differentiate into centroblasts, and proliferate in the dark zone of the germinal centers. Within the dark zone, the centroblasts undergo somatic hypermutation (SHM), which introduces mostly single base-pair changes into the immunoglobulin variable region of the heavy and light chain locus, with the aim of increasing their affinity for the antigen. Centroblasts then move to the light zone, where they differentiate into centrocytes and undergo class-switch recombination (CSR). T-cells and follicular dendritic cells help to rechallenge the centrocytes with the antigen such that cells with a low-affinity immunoglobulin-receptor are eliminated by apoptosis, while a subset of centrocytes with high-affinity to the antigen are selected to differentiate further into memory B-cells or plasma cells. 


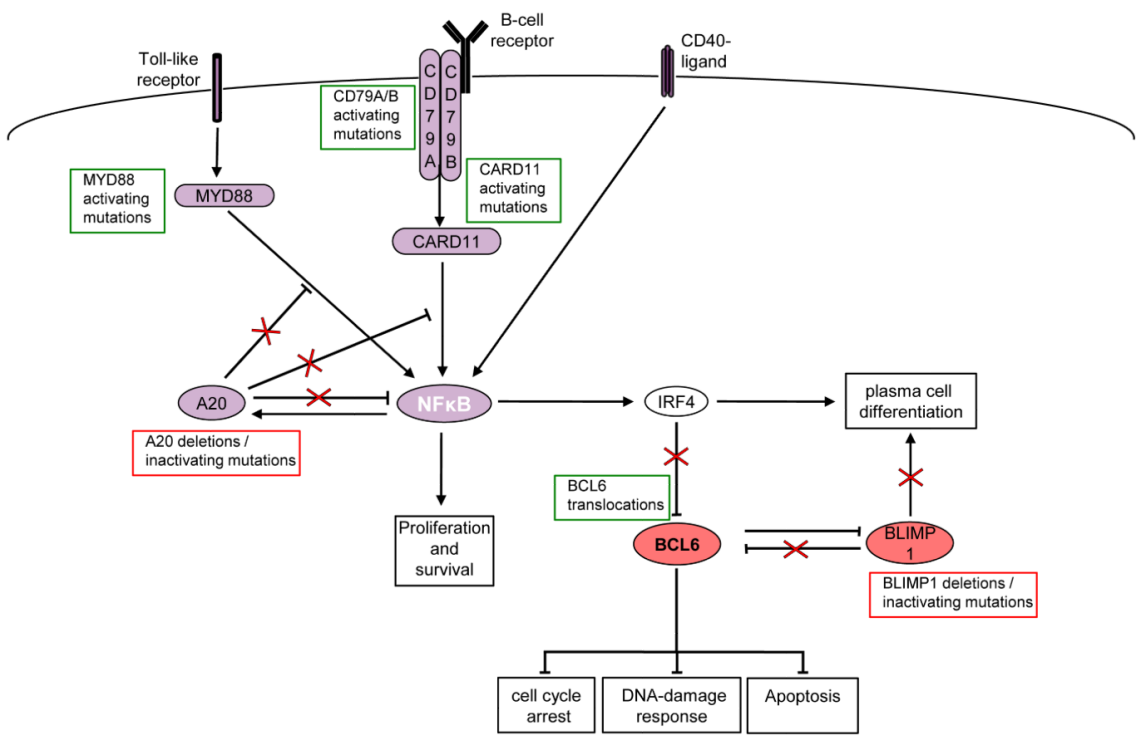

Figure 2.

Oncogenic pathways in ABC-DLBCL

The stimulation of several surface receptors, including the B-cell receptor (BCR), CD40 or Toll-like receptors, triggers signaling cascades resulting in the activation of the NF-kB pathway. In ABC-DLBCL, NF-kB is constitutively activated and several genetic lesions that contribute to this activation have been identified. 
Table 1

Genetic lesions associated with different subtypes of DLBCL.

GCB-DLBCL

\begin{tabular}{|c|c|c|c|c|}
\hline GENE & $\begin{array}{l}\text { GENETIC } \\
\text { ALTERATION }\end{array}$ & FUNCTIONAL CONSEQUENCES & BIOLOGICAL CONSEQUENCES & REFERENCES \\
\hline BCL2 & $\begin{array}{l}\mathrm{t}(14 ; 18) \\
\text { Mutations }\end{array}$ & $\begin{array}{l}\text { Ectopic BCL2 expression } \\
\text { Escape from BCL6-mediated } \\
\text { repression }\end{array}$ & Inhibition of apoptosis & $\begin{array}{l}\text { Weiss et al. } \\
1987 \\
\text { Ci et al. } 2009 \\
\text { Saito et al. } 2009 \\
\text { Rosenwald et al. } \\
2002\end{array}$ \\
\hline MYC & $\begin{array}{l}\mathrm{t}(8 ; 14) \\
\mathrm{t}(2 ; 8) \\
\mathrm{t}(8 ; 22)\end{array}$ & $\begin{array}{l}\text { Ectopic expression } \\
\text { Escape from BCL6-mediated } \\
\text { repression }\end{array}$ & Enhanced proliferation and survival & $\begin{array}{l}\text { Kramer at al. } \\
1998\end{array}$ \\
\hline $\mathrm{EZH} 2$ & activating mutations & $\begin{array}{l}\text { Increase in histone } \mathrm{H} 3 \mathrm{~K} 27 \\
\text { trimethylation }\end{array}$ & Epigenetic reprogramming & $\begin{array}{l}\text { Morin et al. } \\
2010\end{array}$ \\
\hline MLL2 & inactivating mutations & $\begin{array}{l}\text { Decrease in histone } \mathrm{H} 3 \mathrm{~K} 4 \\
\text { trimethylation }\end{array}$ & Epigenetic reprogramming & $\begin{array}{l}\text { Morin et al. } \\
2010 \\
\text { Mendez-Largo } \\
\text { et al. } 2010\end{array}$ \\
\hline MEF2B & point mutations & unknown & unknown & $\begin{array}{l}\text { Morin et al. } \\
2010 \\
\text { Mendez-Largo } \\
\text { et al. } 2010\end{array}$ \\
\hline $\begin{array}{l}\text { CREBBP } \\
\text { EP300 }\end{array}$ & $\begin{array}{l}\text { inactivating mutations/ } \\
\text { deletions }\end{array}$ & $\begin{array}{l}\text { Reduced acetyltransferase activity } \\
\text { Impaired acetylation of BCL6 } \\
\text { Impaired acetylation of p53 }\end{array}$ & $\begin{array}{l}\text { Epigenetic reprogramming } \\
\text { Enhanced BCL6 oncogenic function } \\
\text { Loss of p53 tumor suppressor activity }\end{array}$ & $\begin{array}{l}\text { Pasqualucci et } \\
\text { al. } 2011\end{array}$ \\
\hline PTEN & deletions & Loss of PIP3 negative regulation & Activation of AKT signaling pathway & Lenz et al. 2008 \\
\hline PIK3CA & activating mutations & Increased catalytic activity & Activation of AKT signaling pathway & $\begin{array}{l}\text { Abubaker et al. } \\
2007\end{array}$ \\
\hline BCL6 & $\begin{array}{l}\text { mutations of the B6BS } \\
\mathrm{t}(3 ; \text { other })(\mathrm{q} 27 ; \text { other })\end{array}$ & $\begin{array}{l}\text { Evasion from BCL6 autoregulation } \\
\text { Deregulated expression }\end{array}$ & $\begin{array}{l}\text { Enhanced proliferation } \\
\text { Resistance to apoptosis } \\
\text { Block in differentiation } \\
\text { Impaired DNA damage response }\end{array}$ & $\begin{array}{l}\text { Wang et al. } \\
2002 \\
\text { Pasqualucci et } \\
\text { al. } 2003\end{array}$ \\
\hline REL & gene amplification & Increased gene dosage & Unclear & $\begin{array}{l}\text { Rosenwald et al. } \\
2002\end{array}$ \\
\hline \multicolumn{5}{|c|}{ ABC-DLBCL } \\
\hline GENE & $\begin{array}{l}\text { GENETIC } \\
\text { ALTERATION }\end{array}$ & FUNCTIONAL CONSEQUENCES & MECHANISM OF TRANSFORMATION & REFERENCES \\
\hline $\begin{array}{l}\text { TNFAIP3 } \\
\text { (A20) }\end{array}$ & $\begin{array}{l}\text { biallelic } \\
\text { mutations/deletions }\end{array}$ & Loss of NF-kB negative regulation & $\begin{array}{l}\text { Constitutive NF-kB signaling } \\
\text { Enhanced cell survival }\end{array}$ & $\begin{array}{l}\text { Compagno et al. } \\
2009\end{array}$ \\
\hline CARD11 & activating mutations & Increased NF-kB activation & $\begin{array}{l}\text { Constitutive NF-kB signaling } \\
\text { Enhanced cell survival }\end{array}$ & Lenz et al. 2008 \\
\hline $\begin{array}{l}\text { CD79A } \\
\text { CD79B }\end{array}$ & activating mutations & $\begin{array}{l}\text { Increased BCR expression } \\
\text { Reduced activation of Lyn }\end{array}$ & $\begin{array}{l}\text { Constitutive NF-kB signaling } \\
\text { Enhanced cell survival }\end{array}$ & $\begin{array}{l}\text { Davis et al. } \\
2001\end{array}$ \\
\hline MYD88 & activating mutation & $\begin{array}{l}\text { Spontaneous assembly and activity } \\
\text { of IRAK1/ IRAK } 4 \text { complex }\end{array}$ & $\begin{array}{l}\text { Constitutive NF-kB signaling } \\
\text { JAK/STAT signaling activation }\end{array}$ & Ngo et al. 2011 \\
\hline BCL6 & $\mathrm{t}(3 ;$ other $)(\mathrm{q} 27 ;$ other $)$ & Deregulated expression & $\begin{array}{l}\text { Enhanced proliferation } \\
\text { Resistance to apoptosis } \\
\text { Block in differentiation } \\
\text { Impaired DNA damage response }\end{array}$ & $\begin{array}{l}\text { Ye et al. } 1993 \\
\text { Kerckaert et al. } \\
1993 \\
\text { Iqbal et al. } 2007\end{array}$ \\
\hline $\begin{array}{l}\text { PRDM1 } \\
\text { (BLIMP1) }\end{array}$ & biallelic mutations/ deletions & Loss of PRDM1 function & Block in differentiation & $\begin{array}{l}\text { Pasqualucci et } \\
\text { al. } 2006 \\
\text { Tam et al. } 2006 \\
\text { Mandelbaum et } \\
\text { al. } 2010\end{array}$ \\
\hline
\end{tabular}


GCB-DLBCL

\begin{tabular}{|c|c|c|c|c|}
\hline GENE & $\begin{array}{l}\text { GENETIC } \\
\text { ALTERATION }\end{array}$ & FUNCTIONAL CONSEQUENCES & BIOLOGICAL CONSEQUENCES & REFERENCES \\
\hline BCL2 & gene amplification & Enhanced expression of BCL2 & Inhibition of apoptosis & $\begin{array}{l}\text { Monni et al. } \\
1997\end{array}$ \\
\hline INK4a/ARF & homozygous deletion & Loss of function & $\begin{array}{l}\text { Inhibition of apoptosis } \\
\text { Inactivation of the } \mathrm{p} 53 \text { pathway }\end{array}$ & Lenz et al. 2008 \\
\hline \multicolumn{5}{|l|}{ PMBL } \\
\hline GENE & $\begin{array}{l}\text { GENETIC } \\
\text { ALTERATION }\end{array}$ & FUNCTIONAL CONSEQUENCES & MECHANISM OF TRANSFORMATION & REFERENCES \\
\hline JAK2 & gene amplification & Increased gene dosage & $\begin{array}{l}\text { Enhanced proliferation and cellular } \\
\text { transformation }\end{array}$ & $\begin{array}{l}\text { Guiter et al, } \\
2004\end{array}$ \\
\hline $\begin{array}{l}\text { PDL1 } \\
\text { PDL2 }\end{array}$ & gene amplification & Increased gene dosage & $\begin{array}{l}\text { Evasion of T-cell mediated immune } \\
\text { response }\end{array}$ & $\begin{array}{l}\text { Rosenwald et al. } \\
2003 \\
\text { Green et al. } \\
2010\end{array}$ \\
\hline SOCS1 & homozygous deletion & Loss of JAK2 degradation & Enhanced JAK2 signaling & $\begin{array}{l}\text { Mestre et al. } \\
2005 \\
\text { Melzner et al. } \\
2005\end{array}$ \\
\hline TNFAIP3 & mutations/deletions & Loss of NF-kB negative regulation & $\begin{array}{l}\text { Constitutive NF-kB signaling } \\
\text { Enhanced cell survival }\end{array}$ & $\begin{array}{l}\text { Schmitz et al. } \\
2009\end{array}$ \\
\hline REL & gene amplification & Increased gene dosage & Unclear & $\begin{array}{l}\text { Bentz et al. } \\
2001 \text {, } \\
\text { Wessendorf et } \\
\text { al. } 2007\end{array}$ \\
\hline
\end{tabular}

